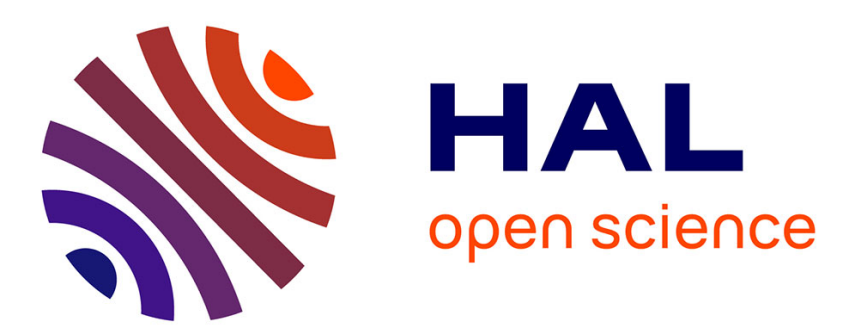

\title{
An organizational learning perspective of the contracting process
}

Fabrice Lumineau, Marc Fréchet, Dominique Puthod

\section{To cite this version:}

Fabrice Lumineau, Marc Fréchet, Dominique Puthod. An organizational learning perspective of the contracting process. Strategic Organization, 2011, 9 (1), pp.8-32. 10.1177/1476127011399182 . halshs-01019320

\section{HAL Id: halshs-01019320 \\ https://shs.hal.science/halshs-01019320}

Submitted on 7 Jul 2014

HAL is a multi-disciplinary open access archive for the deposit and dissemination of scientific research documents, whether they are published or not. The documents may come from teaching and research institutions in France or abroad, or from public or private research centers.
L'archive ouverte pluridisciplinaire HAL, est destinée au dépôt et à la diffusion de documents scientifiques de niveau recherche, publiés ou non, émanant des établissements d'enseignement et de recherche français ou étrangers, des laboratoires publics ou privés. 


\title{
AN ORGANIZATIONAL LEARNING PERSPECTIVE ON THE CONTRACTING PROCESS
}

\author{
Fabrice Lumineau \\ University of Technology Sydney \\ P.O. Box 123 \\ Broadway NSW 2007 \\ Australia \\ Email: fabrice.lumineau@uts.edu.au

\section{Marc Fréchet} \\ Université Toulouse Capitole \\ 2 rue du Doyen Marty \\ 31042 Toulouse cedex \\ Email: marc.frechet@iae-toulouse.fr
}

\section{Dominique Puthod}

Université de Savoie

4 chemin de Bellevue

74944 Annecy le Vieux cedex

France

Email: dominique.puthod@univ-savoie.fr 


\title{
AN ORGANIZATIONAL LEARNING PERSPECTIVE \\ ON THE CONTRACTING PROCESS
}

\begin{abstract}
The contracting process is a crucial step in alliance development and its success. However, the existing literature reveals surprisingly little investigation into how organizational learning relates to the process of contract making. We therefore conducted an in-depth longitudinal study of the alliance contracting process in the animated film industry. First, our findings suggest that during the contracting process, firms can learn about the way to deal with the contracting process, about themselves and their partner, and about the transaction features. Second, the case analysis indicates a combination of experiential, vicarious, and inferential learning mechanisms. Combining these insights into the objects and the mechanisms of learning during the contracting process, we discuss how contracting and learning processes are related and analyze the role of the contracting process in supporting organizational learning. The findings show that the drafting of contractual clauses fosters learning and, in turn, this learning triggers new contractual negotiations. Hence we suggest that the alignment between transaction features and the choice of contractual governance results from learning during the contracting process. We then propose avenues for future research.
\end{abstract}

\section{Keywords}

Contracting process; strategic alliances; organizational learning; longitudinal case study 
Acknowledging that contracts account for a substantial part of future alliance performance, strategy and organization researchers have paid increasing attention to the structure of alliance contracts (e.g. Lumineau and Malhotra, 2011; Reuer and Ariño, 2007; see Weber, Mayer, and Wu, 2009 , for a recent review). Scholars have in particular started to explore how learning relates to contracts (Argyres, Bercovitz, and Mayer, 2007; Dekker and Van den Abbeele, 2010; Mayer and Argyres, 2004; Ryall and Sampson, 2009; Vanneste and Puranam, 2010). Prior research has generally analyzed learning effects from one contract to the next. It has been suggested that the structures of contracts change over time as the firms gain experience in working together (Argyres et al., 2007; Mayer and Argyres, 2004). However, as the contract is generally seen as an outcome of the parties foreseeing hazards and the focus is mostly on the contractual structure, we still do not know much about what is learned during the contracting process and how this learning occurs. In addition, the processes preceding alliance formation, and particularly the process of contract making, have received very little attention (Ariño and Ring, 2010; Ring, 2006; Vlaar, Klijn, Ariño, and Reuer, 2010).

In this paper, our aim is to develop a better understanding of the links between the contracting process and learning. Our study elaborates on organizational learning (e.g. Argote and MironSpektor, 2011; Inkpen and Tsang, 2007) in order to analyze learning dimensions in the alliance contracting process. While considering the structure and the content of the contract, our approach focuses on the process that the parties use to draft the contract (Macneil, 1980). We seek to improve our knowledge of alliance contracting by studying both the objects and the types of learning during the contracting stage. We specifically explore the two following research questions: What is learned during the contracting process? and How is it learned? In view of the limited existing theory and empirical evidence, we use an in-depth case study to address our research questions. We conducted an exploratory longitudinal case study in the 
animated film industry and followed contracting and learning processes over 17 months in a nonretrospective manner. This processual analysis outside the laboratory enables us to obtain a number of insights into the contracting process.

Our research complements recent studies that have started to bring together learning and contracting perspectives in several ways. We highlight three main objects of learning for the firm: learning about the contracting process, learning about itself and the partner, and learning about the transaction features. Moreover, while previous studies have focused on learning by experience, we reveal a specific combination of three mechanisms of underlying learning processes during this stage of contractual making: experiential, vicarious, and inferential. This finding leads us to discuss how contracting and learning processes are related.

\section{THEORETICAL BACKGROUND}

Our theoretical focus is based on three streams within the literature: interfirm contracts, organizational learning in alliances, and alliance processes. Following an overview of each of them, we will look at the bridges that have been built to date between these approaches. We will then identify some important gaps and introduce our research questions.

\section{Traditional approaches to interfirm contracts}

The last two decades have seen a surge in interorganizational and alliance contract-focused studies. This research has mostly drawn on economic theories around transaction cost economics (Williamson, 1975, 1985), agency theory (Holmström and Milgrom, 1991; Jensen and Meckling, 1976), and property rights theory (Grossman and Hart, 1986; Hart and Moore, 1988). Empirical research has variously studied discrete contract provisions (e.g. Crocker and Masten, 1988; Joskow, 1987; Kalnins and Mayer, 2004), contractual complexity (e.g. Parkhe, 1993; Poppo and 
Zenger, 2002), and contractual functions (e.g. Chen and Bharadwaj, 2009; Malhotra and Lumineau, 2011; Reuer and Ariño, 2007). For instance, the TCE approach emphasizes the need for an alignment between transaction attributes and contract characteristics (Williamson, 1985). The content of a contract (e.g. safeguards, penalties, auditing rights) is supposed to respond to the attributes of the transaction in terms of perceived opportunism risk, uncertainty, and asset specificity to minimize transaction costs (Sampson, 2004). The contract is seen as an outcome where farsighted parties look ahead, recognize hazards, and devise hazard mitigating responses (Williamson, 1999: 1090). Although it is recognized that actors are constrained by their bounded rationality while contracting (Williamson, 1985: 8), this literature does not say much about how actors may actually cope with their limited cognitive capabilities in elaborating a contract. Within this perspective, previous research has focused on the structural dimension of contractual governance. Contracting is therefore generally considered "as a once-and-for-all activity rather than as an evolving process requiring significant learning" (Argyres et al., 2007: 4). In fact, TCE has not yet fully incorporated learning into its theoretical framework (Williamson, 1999). This partly explains why prior research has largely focused on equilibrium contract designs and has rarely dealt with the nature of contractual learning processes (Argyres et al., 2007; Argyres and Mayer, 2007).

\section{Organizational learning in alliances}

The view of alliances as a vehicle for learning is the basis for an important body of research (see Inkpen and Tsang, 2007, for a review). Most studies on alliance learning have focused on experiential learning — such as trial-and-error or learning-by-doing — which is the process of making meaning from direct experience (Heimeriks, 2010; Prange, 1999). This type of learning covers the knowledge acquired through reflection on doing and accumulating experience (Argote, 
1999). Studies that bring interfirm contracts and organizational learning together also focus on one type of learning, namely, experiential learning. In their seminal study, Mayer and Argyres (2004) look at contracting as a capability that firms are able to learn. As the relationship progressed, two contractual partners gradually learned how the other operated and this knowledge enabled them eventually to incorporate contract terms that took such factors into account. However, these authors insist that learning is essentially based on firms' mutual experience. We find this same focus on experiential learning in most of the other studies concerning interorganizational contracting (Dekker and Van den Abbeele, 2010; Faems, Janssens, Madhok, and Van Looy, 2008; Ryall and Sampson. 2009; Vanneste and Puranam, 2010).

Some studies on alliances have suggested that other types of learning exist besides experiential learning. In particular, some scholars have shown the presence of deliberate learning-that is, a type of learning process that relies on an explicit commitment on the part of firms, such as knowledge codification, cognitive efforts, or specific managerial attention (Simonin, 1997; Heimeriks and Duysters, 2007; Kale, Dyer, and Singh, 2002; Kale and Singh, 2007; Zollo and Winter, 2002). As pointed out by Zollo and Singh (2004: 1238), such a distinction between different types of learning is theoretically important because it assumes different underlying behavioral and cognitive processes. Looking at different sources of learning is also important for taking full advantage of the learning properties of alliances. However, the possibility of different types of learning has not yet been directly explored in contracting studies.

Moreover, prior research has focused on how learning from working together has been manifested in the design of the contract (e.g. Dekker and Van den Abbeele, 2010), but we still know little about learning about the contracting process. For instance, Vanneste and Puranam (2010) specifically show that the learning effect is stronger for technical than for legal detail in contracts. Mayer and Argyres (2004) suggest that learning to contract not only concerns better contract 
structures but also deals with how to collaborate more generally. Their findings indicate that firms may learn how to use contracts to manage their interfirm relationships over time. These authors then suggest that changes to the contractual structure mainly derive from learning how to work together, including how to contract with each other. Moreover, Argyres et al. (2007) find that some clauses behave as complements in contractual design and such a complementarity reflects the fact that firms may learn to achieve fit in their contract designs. Their study therefore implies that an understanding of contracts requires "going beyond equilibrium analysis to seek an understanding of the nature of contractual learning processes" (Argyres et al., 2007: 15).

\section{Processual approaches on alliances}

A number of studies adopting processual approaches (Szulanski, Porac, and Doz, 2005; Van de Ven, 1992) have challenged the static vision stemming from TCE (e.g. Ariño and de la Torre, 1998; Doz 1996; Koza and Lewin, 1998; Kumar and Nti, 1998; Ring and Van de Ven, 1992, 1994; Zajac and Olsen, 1993). Dynamic approaches often view processes in alliances as cycles in which the outcome of collaboration is implemented and assessed. Depending on their assessment, firms undertake corrective actions, which lead them to set new conditions of cooperation. As pointed out by Das and Kumar (2007), while the notion of learning shaping alliance is implicitly embedded in those processual frameworks, only Doz (1996) and Kumar and Nti (1998) explicitly deal with the impact of learning on alliance evolution. For Doz (1996), learning cycles cumulate over time as participants progressively make increasing commitments to the alliance. Kumar and Nti (1998) develop a dynamic theoretical framework of alliances in which learning-related discrepancies may threaten commitment in the relationship. These two studies suggest sequences of learning, reevaluation, and readjustment stages following the accumulated experience. 
Furthermore, recent reviews on alliance processes (Bell, den Ouden, and Ziggers, 2006; Salk, 2005; Vlaar et al., 2010) note that the literature has essentially paid attention to the post-agreement processes - that is, after firms have signed a formal agreement. Scholars generally take the various forms of structural governance as the starting point. However, we still do not know much about the pre-agreement processes. In fact, the actual process of negotiating and drafting contracts has been somewhat neglected (Faems et al., 2008; Ring, 1997). Moreover, contractual changes are generally analyzed from one contract to the next (e.g. Mayer and Bercovitz, 2008; Ryall and Sampson, 2009; Vanneste and Puranam, 2010), without considering the formation stage of the contract. It therefore appears that despite the interesting avenues opened up by prior research, our understanding of contractual learning processes seems bounded by four related limitations in the existing literature: (a) a focus on contracts as outcomes, (b) a focus on experiential learning, (c) a limited focus on the content of the learning processes, and (d) a focus on post-agreement stages of alliances. In this study, we specifically explore the two following research questions: What is learned during the contracting process? and How is it learned?

\section{METHODS}

\section{A single case study analysis}

Given limited prior theory and empirical evidence, we use an in-depth case study to address our research questions. First, the detailed analysis of a single case is consistent with our theory building effort around unexplored questions (Edmonson and McManus, 2007; Yin, 2009). Second, the difficulty of obtaining detailed contract information has limited the empirical investigation of contracts (Chen and Bharadwaj, 2009), especially in regard to learning aspects. Third, while alliance learning processes have received limited attention (Inkpen, 2002), Inpken and Tsang (2007: 494) note that "one of the research challenges in this area is methodological. [...] To 
develop an understanding of complex alliance learning processes, the researcher must have deep and extensive access to the actual working of the alliance and alliance-partner interactions." Since most previous studies have relied on cross-sectional data, they cannot examine the dynamics of learning over time in an unfolding partnership. Qualitative data offer insight into complex social processes that quantitative data cannot easily reveal (Eisenhardt and Graebner, 2007). With our longitudinal study, we are thus able to respond to many recent calls for a finer understanding of the collaborative dynamics in alliances (Faems et al., 2008; Reuer, Zollo, and Singh, 2002; Vanneste and Puranam, 2010).

\section{Research setting}

We observed and studied a firm involved in an alliance formation in the animated film industry for a period of 17 months. The focal firm, Rosacom (names of the companies have been altered for reasons of confidentiality), is a small French organization employing 25 persons and specializing in visual communication. It acquired the exclusive rights to a famous toy and thus wanted to use these rights to create a series of short cartoon episodes for children. However, such a project entails substantial investment (about $€ 3$ million), which is beyond the reach of this small firm. To gain access to substantial financial resources and thereby enter the animated film industry, Rosacom decided to use an alliance. It therefore contacted Mediacorp, a publicly owned company (with sales of about $€ 120$ million) that produces television series, television films, and cartoons. Mediacorp — located in Paris — and Rosacom—-located 300 miles away in the provinces—-had no prior or other contemporaneous deals together.

In the past decade, the animated film industry has experienced major changes with the

development of computer-generated imagery. Computer-animated films rely on complex technical and creative capabilities and animated film budgets are much higher than they used to be. As a 
result, animated films are now receiving greater recognition and are not simply limited to being "kids' films."

This case is particularly well suited to address our research questions for several reasons. First, we had an opportunity for extremely unusual research access. We were able to collect data and make observations in a longitudinal way from the very beginning of the alliance process. Access to realtime data in the very early stages of alliance formation processes is very hard to obtain (see Ariño and Ring, 2010, for an exception). The few case studies in this field have generally used

retrospective data (e.g. Ariño and de la Torre, 1998; Doz, 1996; Faems et al., 2008). Second, while previous research has tended to view organizations involved in transaction as homogeneous agents (e.g. Inkpen and Currall, 2004), often gathering data from only one informant, we were allowed to interview all the knowledgeable informants in the focal firm. Third, we had access to each version of the contract, something that is hard to obtain because scholars studying interfirm contracts are often confronted with confidentiality issues (Ring, 2002; Weber et al., 2009). Fourth, we chose to study this firm because its managers had little experience in contract making in a new industry, which makes the learning mechanisms more visible (Argote, 1999).

\section{Data collection and analysis}

One of the authors attended, in a nonparticipative way (Van der Velde, Jansen, and Anderson, 2004), all the meetings between Rosacom and Mediacorp from August 2005 (the first discussions between the firms) to December 2006 (the actual launch of the alliance). Other nonparticipant observational data, such as pre- and post-meeting observations and other general on-site interactions, were collected to achieve greater understanding of specific practices (Van Maanen, 1979). Memos and detailed field notes were written to capture our feelings and thoughts on what we observed. We also had access to extensive archival data (contractual documents, minutes of 
meetings, emails, etc.). In addition, we conducted 37 formal interviews over this period, ranging from one to three hours in length. We tape-recorded and transcribed each interview within 24 hours.

As we conducted successive interviews, we specifically asked the interviewee each time what had happened in the negotiation and contract drafting process since the preceding interview. We also left them to speak freely about their perception of the ongoing alliance formation. When actors mentioned a document, we used it as a basis of our discussion and they commented on it in front of us. We consistently asked interviewees to describe the chronology of events that led to contract changes. Following prior research (Argyris and Schön, 1978; Inkpen, 2000), we considered that organizational learning occurs when knowledge is processed and the range of potential behaviors increases. Learning may result in new insights and awareness and need not necessarily lead to observable changes in behavior (Friedlander, 1983; Huber, 1991).

Our progressive data collection allowed us to mitigate retrospective rationalization, selective memory effects, and impression management (Eisenhardt and Graebner, 2007). Moreover, we tried to reduce potential informant biases by comparing data from different interviewees to get complementary perspectives on the same event (Cardinal, Sitkin, and Long, 2004; Golden, 1992). To improve the validity of our analysis, we also combined observations, interviews, and archival data (Eisenhardt, 1989). Triangulation between multiple sources of evidence provides greater accuracy and depth across different perspectives (Golden, 1992; Yin, 2009). Furthermore, we believe that the anonymity and confidentiality maintained throughout the study reduced the effects of social desirability bias (Konrad and Linnehan, 1995).

We analyzed the longitudinal data by using a combination of narrative, bracketing, and visual mapping strategies (Langley, 1999). From the data, we built an extensive narration of the relationship, from which we extracted information on the dynamics of contract formation and the 
nature and conditions of learning.

\section{INTERTWINED DYNAMICS BETWEEN NEGOTIATIONS AND CONTRACTUAL DOCUMENTS}

The discussions between Rosacom top managers and the Mediacorp representative started in August 2005. It was the first time these two firms had done business together and Rosacom managers had no experience in managing or drafting contracts in this new industry. They therefore asked their partner Mediacorp to write a first version of the contract, which had to reflect their initial negotiations. From this point, there were five successive contract versions, with the fifth version actually being signed and becoming the contract used for the alliance. To facilitate the analysis, Figure 1 displays the main stages of the Rosacom-Mediacorp contracting process as well as details for each stage.

— Insert Figure 1 about here —_

The first version of the contract was entirely drafted by Mediacorp (Stage I). When the Rosacom managers received this version, they carefully read it using a legal consultancy. However, after several interviews and discussions about this first version of the contract, Rosacom managers decided to rely on a lawyer who specialized in intellectual property rather than their usual lawyer. The consulting lawyer observed that the contract was not sufficiently detailed and advised the Rosacom managers to renegotiate the agreement with Mediacorp. In response to their legal counsel's advice, Rosacom managers asked their partner to produce a more detailed second draft. Mediacorp then drafted the second version of the contract (Stage II). At this stage, the Rosacom managers called on further external experts to help them to analyze the contract. Both the consultant and the lawyer supporting Rosacom reacted strongly to the clause relating to the exploitation of the series. They strongly recommended that Rosacom offer a new contract to 
Mediacorp and their recommendations applied to most of the re-drafting of the contract. During this process of contract drafting and interpretation of certain clauses, Rosacom managers progressively revised their opinion about their trading partner. When Mediacorp received the third version (Stage III), its chief negotiator observed that it was substantially different from the second version. He then asked for a meeting to negotiate the details of certain points. However, at this stage, Rosacom was more aware of the real value of its contribution to the project and therefore decided to adopt a more aggressive stance in negotiations. After this new round of negotiations, the consultant again pointed out some imprecisions in the contract. Following the legal consultant's recommendations (Stage IV), the two Rosacom managers then asked for another meeting with Mediacorp. The parties finally achieved a mutually satisfactory contract, which was then signed (Stage V).

Our analysis of the five successive contract versions is summarized in Table 1 and Figure 2. In Table 1, we focus on the evolution of the contractual content. We highlight the different versions of two key clauses in the Rosacom-Mediacorp alliance: the clause concerning the marketing and merchandising of the series of cartoon episodes and the clause concerning the location of art management.

— Insert Table 1 about here ——

Figure 2 reports our analysis of the evolving contractual complexity. In line with previous research, we measured both the total length of the contract (e.g. Poppo and Zenger, 2002) and the total number of clauses (e.g. Parkhe, 1993).

\section{— Insert Figure 2 about here -}

Interestingly, both this content analysis of two major clauses and this simple count analysis highlight a nonlinear development of the contract. Although the third version is the longest (6211 words for 25 clauses; i.e. an average of 248 words per clause), the fifth version contains the most 
detailed drafting (5932 words for 21 clauses; i.e. an average of 282 words per clause, a ratio 13.7\% higher than in the third version).

\section{THE OBJECTS AND MECHANISMS OF LEARNING IN THE CONTRACTING PROCESS}

The data provide evidence for three main objects of learning: learning about the contracting process, learning about the firm itself and the partner, and learning about the transaction features. Moreover, the data suggest a specific combination of three types of learning: experiential, vicarious, and inferential.

\section{The objects of learning}

About the contracting process

Our field data show that during the contracting process, Rosacom progressively improved its knowledge about the allocation of resources and, in particular, the use of experts, as well as its general knowledge of the contract role and structure.

During the observed stage of contract making, Rosacom managers learned to solicit, gather, and use advice from competent professionals. For instance, Rosacom managers discovered the limitations of their usual lawyer and finally sought the services of a specialized lawyer (Stage I.1). It is interesting to note that this rather simple lesson was learned through the contracting process and not in some other way. While our focal firm could have easily and quickly learned about the right experts to mobilize for such a project through other means (through professional meetings, for example), it decided to bear these heavy additional costs when their initial lawyer was confronted with the writing of the contract. Likewise, Rosacom managers progressively learned about the consultant's knowledge and past experience and decided to expand his role by having 
him participate in writing the contract (Stage II.1). This change induced modifications in process organizing, which in turn modified interactions between the contract and negotiation trajectories. Accordingly, Rosacom managers sharpened their perception of who had the relevant knowledge in a given situation. Learning here mainly concerned the ability to call on the right expert at the right time in order to apply their knowledge to the alliance contract. This type of learning thus has a "meta" feature to the extent that it does not relate primarily to legal or technical knowledge directly linked to the contractual writings but rather to outlying knowledge.

Consistent with the recognition of the need for a more skilled - and therefore expensive-lawyer, Rosacom managers also modified their perceptions of the contract's importance.

“The initial contract was very short, it's true [...] But in fact, under twenty pages, you can do nothing $[\ldots]$ We now have more than one year of negotiation behind us: imagine if we had signed the contract at the outset!" [Rosacom top manager 2 - Stage IV.3]

The firm's approach to writing the contract changed as managers learned more about the contract's importance. Beyond their general understanding of the contract's legal and protective functions, they became much more aware of the definitional value of the contracting process to align expectations with their partner. Rosacom thus changed the way of allocating resources between contract drafting and operational tasks, in particular by devoting more financial resources to contract making. It also spent more time, accepting that the process was taking longer than expected and was not completed in its early stages.

Similarly, Rosacom managers initially had little idea of how a contract should be structured. During the contracting process, they were given access to templates of intellectual property contracts, which provided them a view of general contract structure and writing in their new industry. For instance, they discovered that a common contracting practice was to set the level of royalties at $30 \%$ and not $35 \%$, as was proposed by the partner (Figure 1, IIa and IIIa). Thus 
Rosacom managers acquired a general knowledge of contract content and organization, and the case analysis provides evidence that the contracting process served as a guide in this way. However, interviews performed at the end of the process suggest that this learning was rather limited. Because they delegated most writing tasks to the lawyers, Rosacom managers are still unable to write a contract themselves, even after the 17-month negotiation period.

\section{About the parties}

It also appears that through the successive analyses of contractual documents, Rosacom learned much about its partner. Although such a finding confirms what was already shown by Mayer and Argyres (2004) in relation to Softstar and its trading partner HW Inc, the analysis of the case suggests a finer distinction between learning about the other party's ability on the one hand and its intentions and expectations on the other hand. Such a distinction is important as it strongly supports different trust mechanisms (Malhotra and Lumineau, 2011).

First, reading and talking about the proposed contractual versions helped Rosacom to get a better idea of Mediacorp's relative strengths and weaknesses in terms of ability and skills. For instance, when Rosacom managers discussed the clause about the artistic stage, they discovered how Mediacorp's corporate group was organized and how the preproduction stage of the series would be performed by one of its subsidiaries.

"In this clause, it is stated that Mediacorp will not perform the artistic stage itself. Rather, it will be done by one its subsidiaries" [The legal consultant - Stage II.2]

Thus a close reading of the clauses helped Rosacom learn about its partner's real level of expertise and its reliance on a subsidiary to execute a complex part of the project.

Second, Rosacom learned more and more about Mediacorp's real intentions with each draft of the contract. For instance, the analysis of the contractual documents submitted by Mediacorp at stages 
II and III provided information about its real intentions and strategy. Mediacorp provided documents in which the allocation of rights and responsibilities appeared clearly unbalanced and in Mediacorp's favor, with royalties higher than industry standards (Stage II.3). Since Mediacorp said nothing about such changes when they sent the new contract version, Rosacom managers discovered them by chance when reading the contract. The fact that such changes were not negotiated but were surreptitiously put in the contract was perceived by Rosacom as an opportunistic move by Mediacorp. Careful reading of the clause therefore showed Rosacom its partner's potential opportunism and hidden agenda (Stage II.4). The same phenomenon is seen in version IV, in which Mediacorp introduced modifications differing from version III.

“Mediacorp's commission has just jumped back up to $35 \%$... The part indicating that the preproduction stage would be located in [our area] has also disappeared." [The legal consultant, in a sarcastic tone - Stage IV.1]

Such learning through the contracting process about Mediacorp's opportunistic behavior directly triggered new negotiations between the partners. As Rosacom felt it had successfully thwarted Mediacorp's opportunistic attempts, it nevertheless decided not to break the alliance.

Furthermore, during the negotiation process, issues raised by those in charge of contract crafting led Rosacom to reconsider some of its needs and requirements in the alliance. This is particularly striking for the definition of preproduction arrangements (Stages II.2 and III.3, Table 1, b). From the exchanges with Mediacorp, it emerged that Mediacorp considered this point to be very important. As a consequence, Rosacom managers began to suspect that geographic location was a 
major issue in the contract. Rosacom thus progressively viewed this clause as central, indicating that associated property rights granted by the clause were of utmost importance. ${ }^{1}$

"Now we know on which points we will not budge: we will not give in regarding the preproduction stage, which is crucial to us." [Rosacom top manager 2 - Stage II.2].

\section{About the transaction features}

The contract drafts and templates also clarified the transaction features, that is, the specifics of this deal. At the beginning of the negotiations, Rosacom had only a broad and rather hazy idea of the scope of the alliance. Although the general objective was to use its exclusive rights over a toy to develop cartoon episodes, at this stage Rosacom did not know precisely what they wanted to do and what could be accomplished in partnership with Mediacorp. Thus, for this complex and innovative project of animation movie development, an important object of learning was related to the features of the transaction in regard both to its nature and its scope.

The discussion of the successive contractual documents was central for learning about the precise nature of the activities to be implemented. In particular, the parties had to explicitly discuss what was included in and what was excluded from their joint project. For instance, the lawyer noted that some aspects of the project had to be further negotiated because there were some missing clauses from early versions of the contract (Stage I.2).

"From the analysis of the agreement it appears that a certain amount of contractual arrangements have not been considered by the parties and should be discussed in the course of current negotiations." [The lawyer - Stage III.1]

$1 \quad$ We specifically refer to the recent paper by Kim and Mahoney (2010) for a discussion on Coase's (1960) and Alchian's (1977) property rights insights regarding the contractual process as a way to discover key information and new opportunities. We thank an anonymous reviewer for pointing us in this direction. 
The lawyer then developed the description of agreement duration, confidentiality, sanctions, and conflict resolution techniques, referring to standard alliance contract structure and industry templates. Without suggesting any content, he urged the parties to discuss these elements before moving ahead with the alliance contract. Later in the process, the parties used the contract during joint work meetings in order to discuss what they wanted to do together in the alliance (Stage IV.2).

"During the meeting, [Top manager 1] then declared that we would reconsider all the contractual arrangements. We negotiated the wording of the last contract version, paragraph by paragraph. I had with me notes from the lawyer and the legal consultant, which helped me a lot." [Rosacom top manager 2 - Stage IV.2]

Following the trail of drafts allowed new issues to emerge and determined which points of the project had to be refined. In that sense, it guided the parties to determine which points had to be further elaborated. Therefore, learning about the objectives and the general shape and scope of the alliance were clearly driven by the use of contractual documents.

Thus the case study shows that the 17-month contracting process led our focal firm to gain a more accurate appreciation of both what it wanted to do and what it could really do. More precisely, as summarized in Figure 3, learning concerned three related areas: learning about the contracting process, about the parties, and about the transaction features. We now turn to how this learning took place.

— Insert Figure 3 about here -

\section{Learning mechanisms}

Experiential learning 
As is apparent from the case study, experience was a key driver of learning for Rosacom. As managers gained experience with this specific partner and about this particular project, they progressively developed their knowledge in the three fields mentioned above. Our focal firm typically learned through trial-and-error: managers assessed the outcomes of their decisions based on both their partner's and their experts' reactions. Whenever they were dissatisfied with an existing choice, they undertook corrective actions. One piece of evidence for this learning-bydoing is when they discovered the limitations of their usual lawyer; Rosacom managers finally sought the services of a specialized lawyer (Stage I.1).

This finding about an incremental updating based on the interpretation of experience confirms prior research. However, contrary to recent studies that often assume a traditional learning-curve perspective (Vanneste and Puranam, 2010), we did not observe a linear relationship between contractual details and experience (see Figure 2). We further discuss this finding below.

\section{Vicarious learning}

In addition to the learning process based on experience, the analysis of the Rosacom-Mediacorp case indicates that interventions by external parties strongly influenced learning in contracting. This reliance on other parties' knowledge is indicative of vicarious learning (Baum, Li, and Usher, 2000; Kim and Miner, 2007; Terlaak and Gong, 2008).

The interview data indicate that the recourse to experienced acquaintances played a key role in supporting learning during the contracting process. For instance, one manager asked an acquaintance to provide him an example of a contract so that he could use it as a guideline for his own contract. Each of the two experts helping Rosacom - the lawyer specialized in intellectual property and the legal consultant - also supported the acquisition of new knowledge, but they provided access to a wider knowledge base than the acquaintances by insisting both on contract 
content and on contract process. The experts were sometimes crucial in the analysis and interpretation of the contract. They encouraged Rosacom to both codify their intentions for the alliance project in formal terms and to decode the various contractual versions. Not only did they directly teach Rosacom managers certain aspects of contract management, but they also insisted on the fact that they had to be more rigorous when drafting and interpreting contracts. Experts played an important role in helping managers change their perceptions and preconceived ideas about contracts and, on some occasions, needed to insist forcefully to make the managers aware of what was at stake in contract negotiation.

"I have just seen [Top manager 1] and [Top manager 2], and I have shaken them up a bit, we had somewhat harsh words. I found them a rather too casual about contract drafting." [The legal consultant - Stage II.3]

As Rosacom was struggling with a lack of information from its own experience, it used this vicarious learning strategy to gain clues about how to interpret and react to uncertainty and ambiguity.

Thus, interestingly, this finding on the role of experts in supporting learning in the contracting process differs from previous research, which has not pointed out such an influence. For instance, Mayer and Argyres (2004: 398) note that "[1]awyers played no direct role in the negotiation of the [statements of work]." We return to this finding in our discussion.

\section{Inferential learning}

Besides the role of experience and external parties, learning also relied on a process of inferences. Rosacom managers used the contract to form an opinion based on what they already knew and the contract was then used as a basis for reflection and to draw contextualized inferences. This work 
of virtual implementation of the contract repeatedly served as a basis for projection of the future and helped Rosacom managers to assess the relevance of the contractual arrangements.

The assessment of contract modifications not discussed between the partners provides an example of the way in which inferential learning was leveraged during the contracting process. Rosacom managers initially stated orally that the preproduction stage would be located in their geographic area. However, in the two first versions that Mediacorp transmitted to Rosacom, there was no mention of the location (see Table 1, Stages I.1 and II.2). The sources of this omission were ambiguous. The Mediacorp top manager had indeed warned Rosacom managers that he was extremely busy when he prepared the contract and was not sure that it was flawless. Omissions could therefore stem from a lack of attention. Rosacom managers themselves thus added this mention in the third version on which they worked and sent it to Mediacorp (Table 1, Stage III.2). However, in the fourth version that Mediacorp sent back, the mention of the area had again disappeared (Table 1, Stage IV.2). The systematic omission of the geographic area by Mediacorp, while this point was considered important by Rosacom and had been orally agreed upon, led Rosacom managers to develop several hypotheses about Mediacorp's behavior and intentions. This way of analyzing and interpreting the contracting process then encouraged Rosacom to look for further information on this particular point.

It suggests the presence of some inferential learning (Huber, 1991; March, Sproull, and Tamuz, 1991; Miner and Mezias, 1996) during the contracting process. With their limited experience, Rosacom managers made deliberate efforts to enhance their understanding of the alliance project through a simulation of hypothetical future scenarios and a consideration of multiple interpretations of experience. At Rosacom, typical work on the contractual documents involved taking a critical clause and speculating about Mediacorp's potential behavior (for instance, at Stages I.2, II.2, and IV.1). As a way of detecting and correcting loopholes, it enabled Rosacom to 
refine its approach to the contractual process and to improve its ability to contract. This careful examination of different options was a way of organizing and improving their thinking about themselves, their partner, and the alliance project. The building of possible scenarios on the evolution of the alliance served as a guide for choosing among different options as well as for developing new ones. These "thought experiments" (Ricoeur, 1984) enabled Rosacom managers to generate new meanings and consider new actions (Garud, Dunbar, and Bartel, 2011) by leading them to ask how they would react and what would be the implications of a given scenario for a set of contractual choices. Such inferences relied, for instance, on generalization, abstraction, association, and characterization (Michalski, 1994). This type of inferential learning relied on two complementary steps. Rosacom managers interpreted information and tried to make sense of their

partner's behavior. They then made deductions to anticipate a causal connection between what they observed and potential reactions from Mediacorp. They therefore used the contracting process to develop heuristics to guide their behavior on the basis of both reliability-i.e. the generation of an understanding of phenomena - and anticipatory validity - i.e. the construction of causal belief-(March et al., 1991; Oldroyd and Gulati, 2010).

\section{Particular combinations of objects and mechanisms of learning}

The case findings suggest some particular combinations between objects and mechanisms of learning at the different stages of the alliance. As already discussed, learning about the other party was particularly well supported by inferential learning (in addition to experiential learning). In contrast, learning about the contracting process was particularly well supported by vicarious learning (in addition to experiential learning).

In addition, we found evidence of different timing patterns for each type of learning mechanism. The findings indicate a difference in both their chronological order and their respective length. We 
observed that experiential learning developed throughout the contracting process (Stages I to V) as Rosacom progressively accumulated experience. Vicarious learning occurred mostly in the beginning and the middle stages of the contracting process (mostly at Stages II and III). We specifically explained, in particular, how Rosacom relied on external experts to organize the contractual negotiations at the beginning of the process. In contrast, inferential learning mechanisms occurred mostly at the end of the process (mostly at Stage IV). As it took Rosacom time to gather clues, make inferences, and weigh up different options in relation to its partner and the transaction, inferential learning strategies were not used at the beginning of the contracting process.

\section{DISCUSSION}

\section{The supporting role of contracting for learning}

The results reveal characteristics of the contracting process supporting the cognitive activities of organizational learning.

On the one hand, the analysis of the Rosacom-Mediacorp case suggests that the contracting process has properties that helped the parties to separate the complexity of the alliance project into a number of constituent elements for interpretation. The importance of simplification has been pointed out by research in cognitive science, that links simplicity with effective encoding of learning (Broadbent, 1958; Miller, 1956). The detailed drafting of each clause led the firms to codify their respective goals and expectations by breaking down issues. This detailed interpretation and drafting of each aspect of the alliance allowed them to acquire a better grasp of the alliance project. It then reduced the necessary cognitive efforts of protagonists to progressively deal with more complex issues (Bingham, Eisenhardt, and Davis, 2007). The rigorous analysis of each clause and its implications forced the parties to think deeply about each dimension of their 
collaboration. It led the parties to think about their intentions and their views on the alliance and thereby helped them to verbalize their expectations.

On the other hand, the contractual interface forced the articulation of ideas and beliefs around a common reference point. It helped the different parties to focus their attention on a set of common issues and to discuss their choices. The contractual document pushed the parties to reflect and think inside its coherent frame. Thus, beyond the diversity of actors involved in the alliance project, the contract provided a shared format across the two firms. Communication around a standard juridical language in the contract made the convergence between Rosacom's and Mediacorp's corporate cultures and languages easier. For example, the contractual document forced the parties to define key terms and thereby helped them to overcome any misunderstanding linked with their respective corporate jargon. Organizational learning was here supported by the use of this common lexicon that prescribes a means for sharing information (Carlile, 2004; Kellogg, Orlikowski, and Yates, 2006).

We specifically explain below how the contracting process supported experiential, vicarious, and inferential learning processes.

First, the Rosacom-Mediacorp case provides evidence that the contract supported access to information and resources. While it supported the transfer of information across space and organizations, it also supported interaction between the different parties through the successive stages of negotiations. By storing and retrieving information over 17 months, it assisted interorganizational memory around the alliance project. As the acquisition of new knowledge depends critically on a sufficient basis of prior related knowledge (Cohen and Levinthal, 1990; Grant, 1996), this function of organizational memory (Huber, 1991) to store, accumulate, and retrieve information greatly facilitated experiential learning. Not only did the contract serve as a 
storehouse for knowledge and shared memory but this base of common knowledge was also helpful in new knowledge assimilation and absorption.

Second, as we observed from the beginning of the Rosacom-Mediacorp alliance formation, the contracting process constitutes a forum that brings together the protagonists. The contract was used as a virtual meeting place where geographically scattered actors could converge and exchange opinions and ideas. It was a privileged means of initiating communication at different levels: within Rosacom, between Rosacom and its external experts, and between Rosacom and Mediacorp. By supporting the acquisition of Mediacorp and the external experts' information through observation and imitation, this contractual feature facilitated vicarious learning in particular (Levitt and March, 1988).

Third, the case study shows that the contractual process supports the development of inferences. Rosacom had no previous experience in the animation movie industry and it was difficult to know how to organize the alliance launch from scratch. The initial contractual template used by Rosacom managers served as a guide and allowed them to deal with the complexity of the alliance's negotiations. Both for internal discussions and for negotiations with Mediacorp, the contract was used as a management tool to organize the order and the way in which to analyze issues point by point and develop inferences. The contracting process also supported learning through the analysis of scenarios for the alliance.

\section{The dynamics of contracting and learning}

As the findings of the case study suggest, contract and organizational learning are involved in a process that is applied recursively. While previous research has largely focused on the impact of the contract on learning effects (see Mayer and Argyres, 2004: 405-406, for an exception to this), we reveal a mutual relationship between learning and contracting. Our findings suggest that 
drafting contractual clauses fosters learning and, in turn, this learning triggers new cycles of contractual negotiations. We observed numerous feedback loops between the different objects of learning: for example, when the acquisition of knowledge or insights about the partner's real ability led Rosacom to modify the clause about the artistic aspect of the alliance (Stage II.2). In turn, this change fostered new discussions about the exact scope of the project. We have highlighted the progressive development of an interactional framework (Sawyer, 1999; Tsoukas, 2009) which emerges from joint action between the partners through the process of contract making. It appears that the contracting process helped to combine acquisition and integration of knowledge with its transformation and re-arrangement for the alliance project. At the same time, the contract gave an orientation and coherence to the negotiations (Li, Poppo, and Zhou, 2010). The process we observed was not simply a linear succession of stages. The partners repeatedly acquired information, which led them to reconsider their initial contractual choices. What was learned during the contracting process directly affected the contractual governance choice, which, in turn, supported new learning. In this regard, the contract may be more than a flexible and adjustable framework (Llewellyn, 1931: 737; Mayer and Argyres, 2004: 406), as it may also support the cognitive activities of organizational learning during the specific stage of contract making. As well as giving coherence to the negotiations - as a framework - the contract also helps the parties to gather and process information useful for developing an alliance project.

Furthermore, in regard to the types of learning that take place in the contracting process, our study also generates additional insights into how different forces come into play at the same time. Prior studies are divided about the effects of partnering experience on governance structure. Some scholars argue that increased familiarity with the partner enhances the ability to design contractual structures (Dekker, 2004; Poppo and Zenger, 2002), while others argue that partner experience reduces the need for extensive governance structures (Gulati and Nickerson, 2008; Zollo, Reuer, 
and Singh, 2002). Our findings contribute to clarifying the tensions between needs and ability in contracting (Dekker and Van den Abbeele, 2010). Our recursive view suggests that firms learn to make relevant choices and adjust the level of contractual detail based on perceived needs. What is learned from the contracting process about the partner and the transaction helps the parties to adjust their governance choices. At the same time, learning how to make contracts enables them to improve their ability to develop a contract more suited to their needs.

\section{The timing of learning strategies}

The findings reveal specific combinations between objects and mechanisms of learning at the different stages of the alliance, something that has not been explored in previous research on interfirm contracts. It may be that at the initial stage of the contracting process, learning is mostly vicarious and relies on external parties to compensate for the lack of experience with the partner and the transaction features. Learning through other parties may be the quickest way to learn about simple aspects that are easily transferred. Later, it may be that when firms have gained some knowledge about how to organize the contracting process, they will become more aware of the opportunities to develop inferences from the contract. As such a learning mechanism requires much time and attention to be really effective, it might explain why we observed inferential learning mostly at the end of the process. Another potential explanation is that because individuals tend to value learning through their own experience more than the experience of others (March, 2009), when they have the choice between different learning mechanisms, they prefer to rely less on vicarious learning and to emphasize other learning mechanisms. In fact, an impediment to vicarious learning we observed in the case analysis was the skepticism of managers regarding the value of experts' knowledge. In particular, managers perceived the lawyers' emphasis on the importance of the contract structure as a professional bias. Our findings also suggest that at each 
stage of the contracting process, Rosacom combined several learning mechanisms and found alternative mechanisms to complement its experiential learning. It might be that firms may want to "triangulate" the outcomes of different learning mechanisms to cross-examine and validate their findings during the contracting process by leveraging complementarities between different learning mechanisms. While the literature suggests that learning from limited experience presents significant learning challenges (e.g. Baum and Dahlin, 2007; Greve, 2003; Kim, Kim, and Miner, 2009), our case analysis suggests that the contracting process may help firms to reduce this challenge by supporting a combination of multiple learning strategies.

\section{Toward an emerging approach to alignment}

A related implication of our study is that while research has mostly focused on the ex post functions of interfirm contracts to govern the transaction (e.g. Lumineau and Malhotra, 2011; Poppo and Zenger, 2002), we suggest that the contract is also useful ex ante the alliance execution. TCE dictates that "credible contracting is very much an exercise in farsighted contracting, whereby the parties look ahead, recognize hazards, and devise hazard mitigating responses" (Williamson, 1999: 1090) and assumes an alignment of governance mechanisms with given transaction attributes (Williamson, 1985). In addition, our recursive view helps to explain why transaction attributes may not be entirely exogenous for complex projects. As the findings suggest, the transaction characteristics are not necessarily predetermined, since they may be part of the negotiations between the partners during the contracting process. In the same way, the level of uncertainty and the likelihood of partner's opportunism may be progressively evaluated through the contracting process. Some of the transaction attributes may be the result of a socially embedded process of learning between the trading parties. As we have seen with the changing perception of Rosacom toward Mediacorp, formal and informal aspects of the alliance agreement 
were built at the same time. An important part of learning in the contracting process seems to deal with an understanding of the "rules of the game"-that is, how the underlying normative conventions come to complement the formal contract. In our case, as Rosacom progressively understood that Mediacorp would have a pretty rigid approach to enforcing the clauses, it consequently revised its approach to the formal contract. Our analysis therefore suggests an emerging approach of the alignment between transaction attributes and contractual governance that is progressive and results from learning during the contracting process. The different objects of learning - about the parties, the contracting process, and the transaction features - have to be jointly considered, since they directly influence each other. The nature of the relationship with the trading partner during the contracting process influences the contractual choice and the scope of the transaction. The answers to the questions "What is doable in our collaboration?" and "What are we ready to make with this partner?" are not necessarily known at the beginning of the contracting process. Our findings actually indicate that the contracting process is a way of progressively dealing with risks and uncertainty in complex transactions. We thus call for further research looking at the ex ante stages of alliances and developing a processual view of alignment.

\section{Managerial implications}

Contracting is a key challenge that firms face when engaging in alliances (Contractor and Ra, 2000; Faems et al., 2008). We argue that one aspect of alliance management relies on the proper management of the contracting process to enhance the different learning potentialities of contracts. Moreover, alliance managers should address both contractual structure and process. The different parties engaged in the contracting process should be more than "transaction cost engineers" (Gilson, 1984). They should not only focus on the technical ability of the contractual governance 
structure to govern a transaction. As a social activity between trading partners, parties should pay attention to the contracting process.

It is also important for managers to be aware of the limitations of contracts. As the findings suggested, they should keep in mind that too much formalization of the alliance agreement can be harmful, causing rigidity and diminishing trust between the partners (Vlaar, Van Den Bosch, and Volberda, 2007). In addition, the "race to learn" in which partners seek to steal their partner's knowledge as soon as they possibly can —often depicted in the strategic alliance literature (Hamel, 1991; Khanna, Gulati, and Nohria, 1998; Kale, Singh, and Perlmutter, 2000) — is already at work at the stage of contract making even before the beginning of the alliance execution. As the contracting process represents some sunk costs and a partner-specific investment, a hold-up may occur before the signing of the contract and the actual start of the alliance. Managers should be aware that contracting is a risky process with potential opportunism from the trading partner. That is why managers should also take care to select their partner with a view to developing a fruitful contracting process.

\section{LIMITATIONS AND SUGGESTIONS FOR FUTURE RESEARCH}

Our single case study - although consistent with our revelatory approach — requires caution when generalizing our findings. Since our insights are contextualized in the study of the RosacomMediacorp contracting process, we discuss below the likely influence of three types of factors. First, our analysis is temporally focused on the stage of contract making. The combination of learning mechanisms we observed is likely to be specific to this stage of alliance formation. It may be that at the initial stage of contracting, the lack of experience with the partner and the transaction features constrain the use of experiential learning strategies; whereas once the project is launched, firms tend to focus on experiential learning. It would then explain why previous research on 
learning to contract—having focused on the post-agreement stage and contract execution (e.g. Mayer and Argyres, 2004; Dekker and Van den Abbeele, 2010)—only discusses experiential learning. Thus we identify a complementary line of inquiry to explore (1) the connections between learning in the stage of contract making with learning in contract execution, (2) the relationship (e.g. substitution or complementary effects) between the different types of learning at each stage of the alliance, (3) learning between transactions (same type or different types), and (4) learning with the same partner vs. with different partners.

Second, we studied an alliance around a complex and innovative project-developing a cartoon. For such a creative artistic development, there was no specific predetermined contractual template, leaving much room for negotiations between the parties. Our empirical context was characterized by a high level of uncertainty and ambiguity about the nature of the project, the final product, and the partner. The contract thus had a key role in organizing the exchange. It is likely that the contracting process plays a less important role in simpler or highly routine transactions (Argyres and Mayer, 2007). The different aspects of learning we pointed out are less likely to develop in shorter or less strategically important alliances where the parties devote fewer human and financial resources (e.g. the involvement of external experts such as lawyers) to the contracting process. It would be interesting to look more closely at the type of resources needed to support each type of learning in the contracting process.

Third, the Rosacom-Mediacorp dyad involved considerable asymmetry in terms of size between the parties. The geographical distance between the partners and the absence of a prior relationship may also help explain the role of the contract in supporting learning. It may be, for instance, that firms less distant — in terms of power, location, familiarity, etc. — do not rely so much on the contract to learn about their partner and/or about the transaction features. 
In the same way, our focal firm was a small organization in the animated film industry, with the two top managers in charge of most strategic and operational concerns. Studies analyzing the role of dedicated functions in knowledge accumulation suggest that a firm with a legal department might have learned differently (Argyres and Mayer, 2007). We thus call for further research on the influence of a dedicated alliance function (Kale et al., 2002), organizational routines (Nelson and Winter, 1982), or systematic procedural learning processes (Sarkar, Aulakh, and Madhok, 2009) to capture, leverage, and share both explicit and tacit lessons from the contracting process.

Beyond the limitations directly related to the specificities of our empirical context, our view of the contracting process opens up a number of avenues for future research. We suggest that research on alliance contracts would benefit by going beyond the traditional economic framework, and we invite scholars to pursue our study of the microdynamics of contracting with analysis rooted in other social sciences. We specifically advance some ideas to further our understanding of interfirm contracting and "unpack" contracting and learning dynamics with insights from sociological and psychocognitive approaches.

\section{— Insert Table 2 about here -}

All in all, our research sheds significant light on the theory and practice of the alliance contracting process related to organizational learning and highlights promising pathways for future research. 
TABLE 1

Evolution of main contract clauses

\section{Contract - version I}

Contract - version II

Contract - version III

a. The marketing of TV and

Marketing and

merchandising

of the series videographic rights will be done worldwide exclusively by Mediacorp, which will receive a commission of $35 \%+$ marketing expenses.

a. The marketing of TV and videographic rights will be done worldwide exclusively by Mediacorp, except for territories and other potential coproducers.

The merchandising will be handled worldwide by Mediacorp, which will receive a commission of $35 \%$ on gross revenue + marketing expenses. a. Mediacorp shall be in charge of the marketing of the series worldwide, except for territories which are reserved to other potential producers. The parties agree to establish a distribution contract after this

Agreement and before any marketing implementation.

(...)

The merchandising will be handled worldwide by Mediacorp, which will thereby receive a commission of $30 \%$ on gross revenue and will add marketing expenses up to the limit of $10 \%$ of gross receipt collected.
Contract - version IV

\section{Contract - version V (final)}

a. Mediacorp will be in charge of merchandising worldwide and will receive a commission of $35 \%$ on gross receipt collected + marketing expenses. a. Mediacorp shall handle the marketing of the series

worldwide, except for territories which are reserved to other potential producers. (...)

The merchandising will be done worldwide by

Mediacorp or any of its subsidiary, which will

receive a commission of $30 \%$ for [Country] and 35\% for other countries on gross receipt collected and will add the marketing expenses up to the limit of $10 \%$ of gross receipts collected.

\section{Location of art b. (none) management}

b. The art management and the preproduction of the series will be done by Rosacom (management, storyboard, executive production). The right to the final cut is reserved to the broadcaster. b. The preproduction stage will be located in [territory] under Rosacom's

responsibility which will be the executive producer. Any other choice of preproduction location or executive producer designation is to be submitted in written form from Rosacom. b. The preproduction will be done by Rosacom

(management, storyboard, executive production). The right to final cut is granted to Mediacorp. b. The art management and the preproduction stage are located in [territory] under Rosacom's responsibility (management, storyboard, executive production). The right to final cut is reserved to the broadcaster. 
TABLE 2

\section{Suggestions for future research on contracting and learning processes}

\section{Analysis of the microdynamics of learning in contracting}

\begin{tabular}{|c|c|c|}
\hline & Sociological perspective & Psychocognitive perspective \\
\hline $\begin{array}{l}\text { From the } \\
\text { actors }\end{array}$ & $\begin{array}{l}\text { - Who are the actors? } \\
\text { - What is the relationship between these actors? } \\
\text { - What are their respective interests and agenda? } \\
\text { - What is important for the decision makers? } \\
\text { - What is their formal and informal bargaining } \\
\text { power? } \\
\text { - What are their roles, responsibilities, } \\
\text { incentives, and time frames? } \\
\text { - What is the influence of the cultural, } \\
\text { organizational, and institutional contexts? (role } \\
\text { of the system of beliefs, values, ideologies, } \\
\text { structures, or norms) } \\
\Rightarrow \quad \text { Ariño and Ring, 2010; Bidwell, 2010; } \\
\text { Husted and Folger, 2004 }\end{array}$ & $\begin{array}{l}\text { - What are the different facets of bounded } \\
\text { rationality? } \\
\text { - How do individuals and groups cope with } \\
\text { the cognitive challenges of contracting? } \\
\text { - What is the role of psychocognitive } \\
\text { influences? (e.g. reference level bias, initial } \\
\text { representations, perceptual effect, heuristics, } \\
\text { attribution error, anchoring, role of the affect } \\
\text { and emotions, adaptive preference, or } \\
\text { preference reversal) } \\
\text { - What is the influence of the parties' } \\
\text { psychocognitive background? (i.e. their } \\
\text { experience, age, gender, training, risk profile, } \\
\text { etc.) } \\
\Rightarrow \quad \text { Foss, 2003; Weber, Mayer, and } \\
\text { Macher, } 2011\end{array}$ \\
\hline \multirow[t]{2}{*}{$\begin{array}{l}\text { From the } \\
\text { contract }\end{array}$} & $\begin{array}{l}\text { - How is the contract used in practice? } \\
\text { - What is the role devoted to the contract? } \\
\text { - What are the non legal properties of the } \\
\text { contract? }\end{array}$ & $\begin{array}{l}\text { - How does the contracting process influence } \\
\text { sense making? } \\
\text { - What are the framing effects of contractual } \\
\text { structures? } \\
\text { - How and why contracts may induce different } \\
\text { behaviors and expectations? }\end{array}$ \\
\hline & & $\begin{array}{l}\Rightarrow \quad \text { Lumineau and Malhotra, 2011; Vlaar } \\
\text { et al., 2007; Weber and Mayer, } 2011\end{array}$ \\
\hline
\end{tabular}


FIGURE 1

April 2005 - September 2005

Main stages of the Rosacom-Mediacorp contracting process

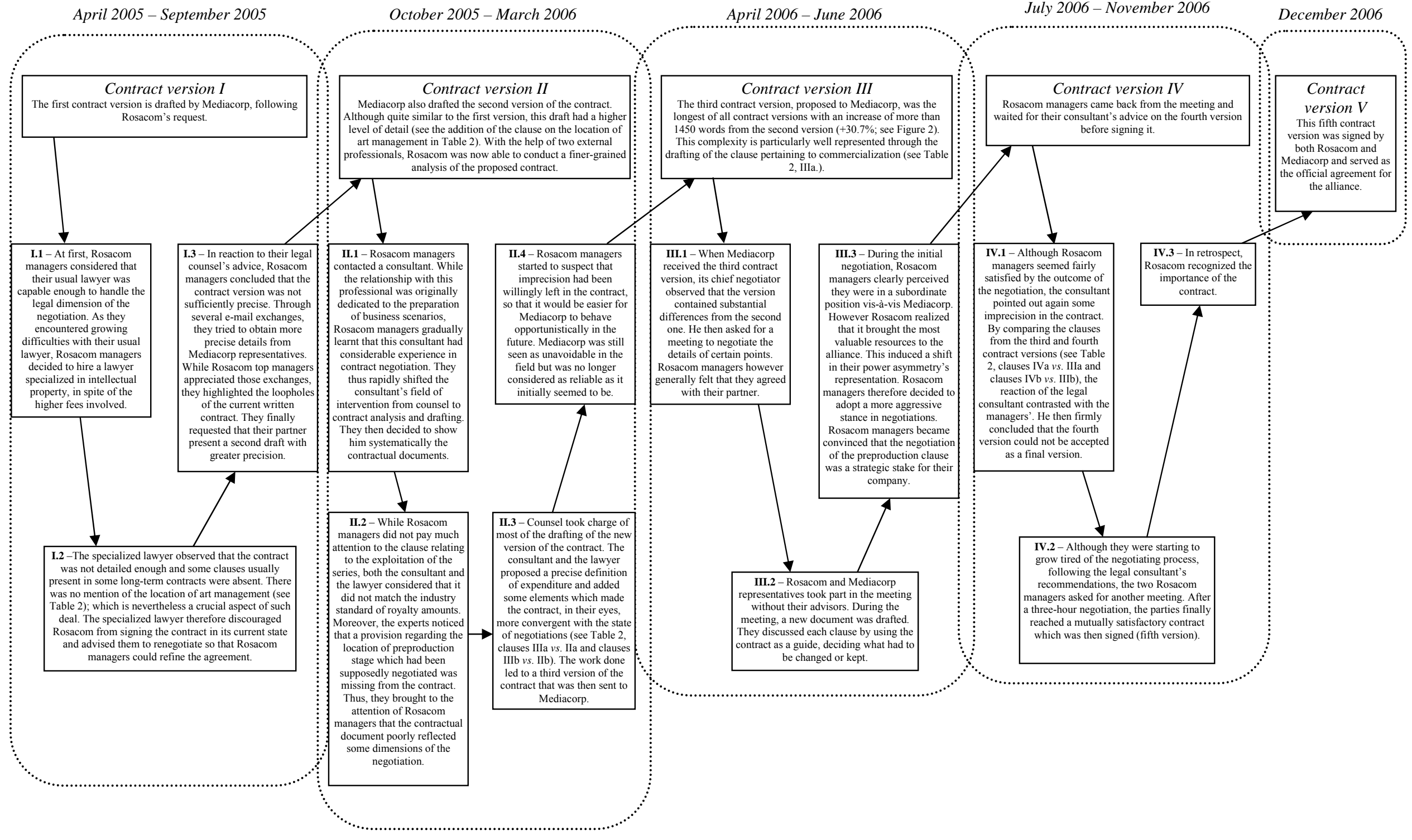


FIGURE 2

General evolution of the alliance contract

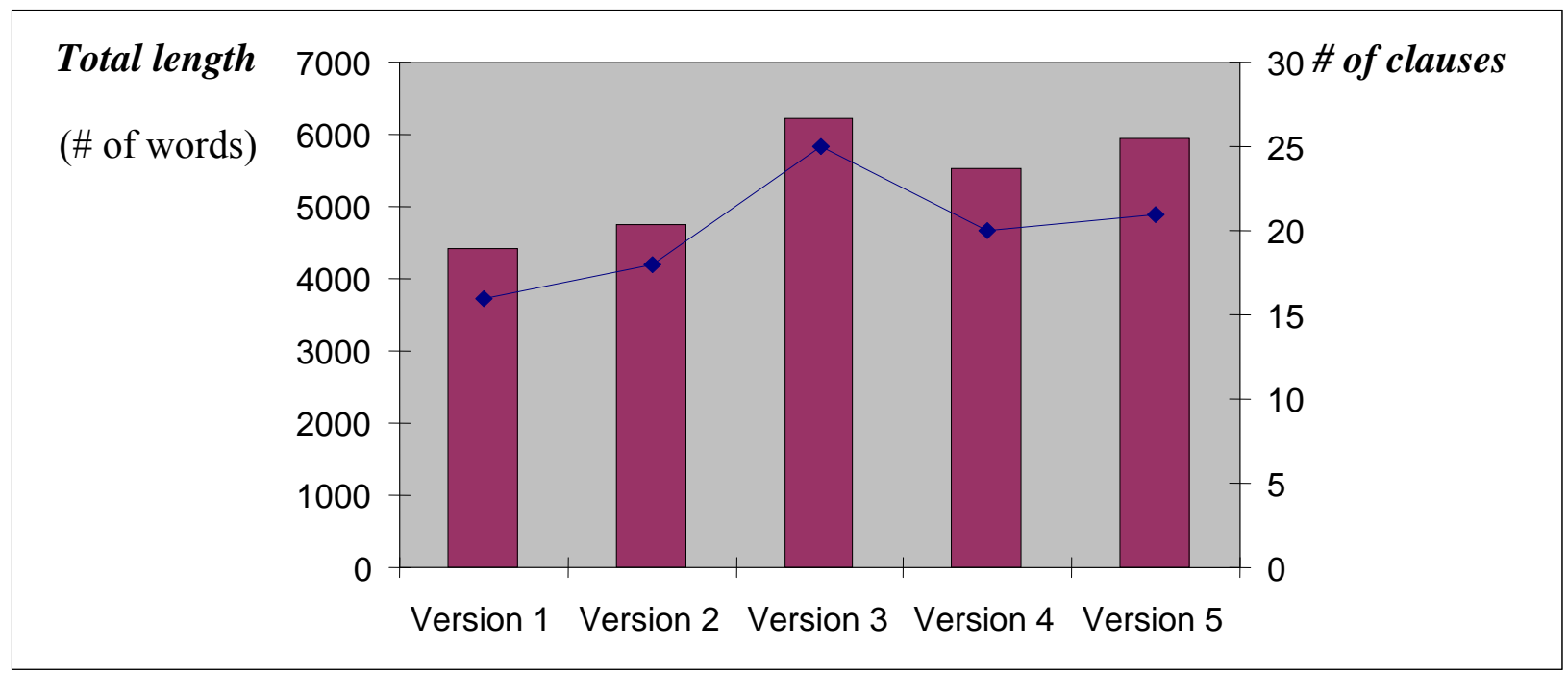


FIGURE 3

\section{Objects of learning in the contracting process}

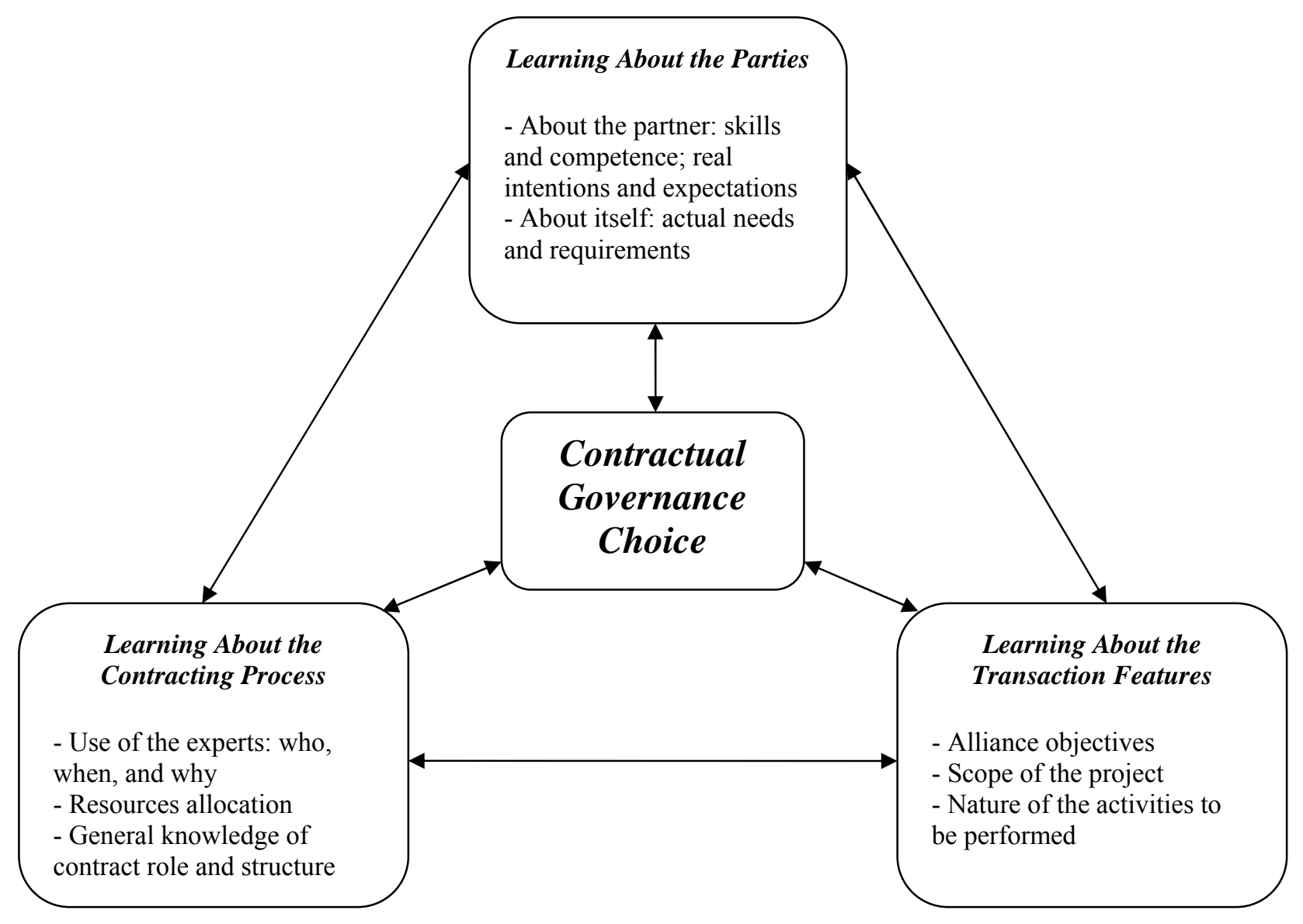




\section{Acknowledgments}

The authors wish to thank Joel Baum and three anonymous reviewers for their excellent feedback on the manuscript. We also gratefully acknowledge the comments of Hélène Delacour, Valérie Duplat, Jan Hohberger, and Philippe Monin. Previous versions of this paper were presented at the University of Technology Sydney, Audencia Nantes, and the Academy of Management meeting in 2008 .

\section{References}

Alchian, A. A. (1977) 'Some Economics of Property Rights', in A. A. Alchian (ed) Economic Forces at Work, pp. 127-49. Indianapolis, IN: Liberty Press.

Argote, L. (1999) Organizational Learning: Creating, Retaining, and Transferring Knowledge. Boston, MA: Kluwer Academic.

Argote, L. and Miron-Spektor, E. (2011) 'Organizational Learning: From Experience to Knowledge', Organization Science. Forthcoming.

Argyres, N. S., Bercovitz, J. and Mayer, K. J. (2007) 'Complementarity and Evolution of Contractual Provisions: An empirical Study of IT Service Contracts', Organization Science 18(1): 3-19.

Argyres, N. S. and Mayer, K. J. (2007) 'Contract Design as Firm Capability: An Integration of Learning and Transaction Cost Perspectives', Academy of Management Review 32(4): 1060-77.

Argyris, C. and Schön, D. (1978) Organizational Learning: A Theory of Action Perspective. Reading, MA: Addison-Wesley.

Ariño, A. and de la Torre, J. (1998) 'Learning from Failure: Towards an Evolutionary Model of Collaborative Ventures', Organization Science 9: 306-25.

Ariño, A. and Ring, P. S. (2010) 'The Role of Fairness in Alliance Formation', Strategic Management Journal 31(10): 1054-87.

Baum, J. A. C. and Dahlin, K. B. (2007) 'Aspiration Performance and Railroads' Patterns of Learning From Train Wrecks and Crashes', Organization Science 18(3): 368-85.

Baum, J. A. C., Li, X. S. and Usher, J. M. (2000) 'Making the Next Move: How Experiential and Vicarious Learning Shape the Locations of Chains' Acquisitions', Administrative Science Quarterly 45(4): 766-801.

Bell, J., den Ouden, B. and Ziggers, G. M. (2006) 'Dynamics of Cooperation: At the Brink of Irrelevance', Journal of Management Studies 43(7): 1607-19.

Bidwell, M. (2010) 'Problems Deciding: How the Structure of Make-or-Buy Decisions Lead to Transaction Misalignment', Organization Science 21(2): 362-79.

Bingham, C. B., Eisenhardt, K. M. and Davis, J. P. (2007) 'Opening the Black Box of Organizational Expertise: Understanding What Firms Learn From their Process Experience and How that Learning Unfolds over Time', Working Paper.

Broadbent, D. E. (1958) Perception and Communication. London, UK: Pergamon Press.

Cardinal, L. B., Sitkin, S. B. and Long, C. P. (2004) 'Balancing and Rebalancing in the Creation and Evolution of Organizational Control', Organization Science 15(4): 411-31.

Carlile, P. R. (2004) 'Transferring, Translating, and Transforming: An Integrative Framework for Managing Knowledge Across Boundaries', Organization Science 15(5): 555-68.

Chen, Y. and Bharadwaj, A. (2009) 'An Empirical Analysis of Contract Structures in IT Outsourcing', Information Systems Research 20(4): 484-506.

Coase, R. H. (1960) 'The Problem of Social Cost', Journal of Law and Economics 3: 1-44. 
Cohen, W. M. and Levinthal, D. A. (1990). 'Absorptive Capacity: A New Perspective on Learning and Innovation', Administrative Science Quarterly 35: 128-52.

Contractor, F. and Ra, W. (2000). 'Negotiating Alliance Contracts: Strategy and Behavioral Effects of Alternative Compensation Arrangements', International Business Review 9: 271-99.

Crocker, K. J. and Masten, S. E. (1988) 'Mitigating Contractual Hazards: Unilateral Options and Contract Length’ RAND Journal of Economics 19(3): 327-43.

Das, T. K. and Kumar, R. (2007) 'Learning Dynamics in the Alliance Development Process', Management Decision 45: 684-707.

Dekker, H. C. (2004) 'Control of Inter-Organizational Relationships: Evidence on Appropriation Concerns and Coordination Requirements', Accounting, Organization and Society 29(1): 2749.

Dekker, H. C. and Van den Abbeele, A. (2010) 'Organizational Learning and Interfirm Control: The Effects of Partner Search and Prior Exchange Experiences', Organization Science 21: 1233-50.

Doz, Y. L. (1996) 'The Evolution of Cooperation in Strategic Alliances: Initial Conditions or Learning Processes?' Strategic Management Journal 17: 55-83.

Edmondson, A. C. and McManus, S. E. (2007) 'Methodological Fit in Management Field Research', Academy of Management Review 32(4): 1155-79.

Eisenhardt, K. M. (1989) 'Building Theories From Case Study Research', Academy of Management Review 14: 532-50.

Eisenhardt, K. M. and Graebner, M. E. (2007) 'Theory Building From Cases: Opportunities and Challenges', Academy of Management Journal 50: 25-32.

Faems, D., Janssens, M., Madhok, A. and Van Looy, B. (2008) 'Towards an Integrative Perspective on Alliance Governance: Connecting Contract Design, Contract Application, and Trust Dynamics', Academy of Management Journal 51 (6): 1053-78.

Foss, N. J. (2003) 'Bounded Rationality in the Economics of Organization: "Much Cited and Little Used"', Journal of Economic Psychology 24(2): 245-64.

Friedlander, F. (1983) 'Patterns of Individual and Organizational Learning', in S. Srivastva (ed) The Executive Mind: New Insights on Managerial Thought and Action, pp. 192-220. San Francisco: Jossey-Bass.

Garud, R., Dunbar, R. L. M. and Bartel, C. A. (2011) 'Dealing with Unusual Experiences: A Narrative Perspective on Organizational Learning', Organization Science. Forthcoming.

Gilson, R. J. (1984) 'Value Creation by Business Lawyers: Legal Skills and Asset Pricing', Yale Law Journal 94: 239-313.

Golden, B. R. (1992) 'The Past Is the Past - Or Is It? The Use of Retrospective Accounts as Indicators of Past Strategy', Academy of Management Journal 35(4): 848-60.

Grant, R. M. (1996) 'Toward a Knowledge-Based Theory of the Firm', Strategic Management Journal 17: 109-22.

Greve, H. R. (2003) Organizational Learning from Performance Feedback. Cambridge, UK: Cambridge University Press.

Grossman, S. and Hart, O. (1986) 'The Costs and Benefits of Ownership: A Theory of Vertical and Lateral Integration', Journal of Political Economy 94: 691-719.

Gulati, R. and Nickerson, J. (2008) 'Interorganizational Trust, Governance Choice, and Exchange Performance', Organization Science 19: 688-708. 
Hamel, G. (1991) 'Competition for Competence and Interpartner Learning within International Strategic Alliances', Strategic Management Journal 12: 83-103.

Hart, O. and Moore, J. (1988) 'Incomplete Contracts and Renegotiation', Econometrica 56(4): $755-85$.

Heimeriks, K. H. (2010) 'Confident or Competent? How to Avoid Superstitious Learning in Alliance Portfolios', Long Range Planning 43(1): 57-84.

Heimeriks, K. H. and Duysters, G. M. (2007) 'Alliance Capability as Mediator between Experience and Alliance Performance: An Empirical Investigation into the Alliance Capability Development Process', Journal of Management Studies 44(1): 25-49.

Holmström, B. and Milgrom, P. (1991) 'Multi-Task Principal-Agent Analysis', Journal of Law, Economics, \& Organization 7: 24-52.

Huber, G. P. (1991) 'Organizational Learning: The Contributing Process and the Literatures', Organization Science 2: 88-115.

Husted, B. W. and Folger, R. (2004) 'Fairness and Transaction Costs: The Contribution of Organizational Justice Theory to an Integrative Model of Economic Organization', Organization Science 15(6): 719-29.

Inkpen, A. C. (2000) 'Learning Through Joint Ventures: A Framework of Knowledge Acquisition', Journal of Management Studies 37(7): 1019-43.

Inkpen, A. C. (2002) 'Learning, Knowledge Management, and Strategic Alliances: So Many Studies, So Many Unanswered Questions', In P. Lorange and F. Contractor (eds) Cooperative Strategies and Alliances, pp. 267-89. Oxford, UK: Elsevier Science.

Inkpen, A. C. and Currall, S. C. (2004) 'The Co-Evolution of Trust, Control, and Learning in Joint Ventures', Organization Science 15: 586-99.

Inkpen, A. C. and Tsang, E. W. K. (2007) 'Learning and Strategic Alliances', Academy of Management Annals 1: 479-511.

Jensen, M. C. and Meckling, W. H. (1976) 'Theory of the Firm: Managerial Behavior, Agency Costs and Ownership Structure', Journal of Financial Economics 3: 305-60.

Joskow, P. L. (1987) 'Contract Duration and Relationship-Specific Investments: Empirical Evidence From Coal Markets', American Economic Review 77(1): 168-85.

Kale, P., Dyer, J. H. and Singh, H. (2002) 'Alliance Capability, Stock Market Response, and Long Term Alliance Success: The Role of the Alliance Function', Strategic Management Journal 23(8): 747-67.

Kale, P. and Singh, H. (2007) 'Building Firm Capabilities Through Learning: The Role of the Alliance Learning Process in Alliance Capability and Firm-Level Alliance Success', Strategic Management Journal 28(10): 981-1000.

Kale, P., Singh, H. and Perlmutter, H. (2000) 'Learning and Protection of Proprietary Assets in Strategic Alliances: Building Relational Capital', Strategic Management Journal 21: 217-37.

Kalnins, A. and Mayer, K. J. (2004) 'Relationships and Hybrid Contracts: An Analysis of Contract Choice in Information Technology', Journal of Law, Economics, \& Organization 20(1): 20729.

Kellogg, K. C., Orlikowski, W. J. and Yates, J. (2006) 'Life in the Trading Zone: Structuring Coordination Across Boundaries in Postbureaucratic Organizations', Organization Science 17(1): 22-44.

Khanna, T., Gulati, R. and Nohria, N. (1998). 'The Dynamics of Learning Alliances: Competition, Cooperation, and Relative Scope', Strategic Management Journal 19: 193-210. 
Kim, J. Y., Kim, J. Y., and Miner, A. S. (2009) 'Organizational Learning from Extreme Performance Experience: The Impact of Success and Recovery Experience’, Organization Science 20(6): 958-78.

Kim, J. and Mahoney, J. T. (2010) 'A Strategic Theory of the Firm as a Nexus of Incomplete Contracts: A Property Rights Approach', Journal of Management 36: 806-26.

Kim, J. Y. and Miner, A. S. (2007) 'Vicarious Learning from the Failures and Near-Failures of Others: Evidence from the U.S. Commercial Banking Industry', Academy of Management Journal 50(3): 687-714.

Konrad, A. M. and Linnehan, F. (1995) 'Formalized HRM Structures: Coordinating Equal Employment Opportunity or Concealing Organizational Practices?', Academy of Management Journal 38: 787-820.

Koza, M. P. and Lewin, A. Y. (1998) 'The Co-evolution of Strategic Alliances', Organization Science 9(3): 255-64.

Kumar, R. and Nti, K. O. (1998) 'Differential Learning and Interaction in Alliance Dynamics: A Process and Outcome Discrepancy Model', Organization Science 9: 356-67.

Langley, A. (1999) 'Strategies for Theorizing From Process Data', Academy of Management Review 24: 691-710.

Levitt, B. and March, J. (1988) 'Organizational Learning', Annual Review of Sociology 14: 319_ 40.

Li, J. J., Poppo, L. and Zhou, K. Z. (2010) 'Relational Mechanisms, Formal Contracts, and Local Knowledge Acquisition by International Subsidiaries', Strategic Management Journal 31(4): 349-70.

Llewellyn, K. (1931) 'What Price Contract? An Essay in Perspective', Yale Law Journal 40: 704 51.

Lumineau, F. and Malhotra, D. (2011) 'Shadow of the Contract: How Contract Structure Shapes Inter-Firm Dispute Resolution', Strategic Management Journal. Forthcoming.

Macneil, I. R. (1980) The New Social Contract: An Inquiry Into Modern Contractual Relations. New Haven, CT: Yale University Press.

Malhotra, D. and Lumineau, F. (2011) 'Trust and Collaboration in the Aftermath of Conflict: The Effects of Contract Structure', Academy of Management Journal. Forthcoming.

March, J. G. (2009) The Ambiguities of Experience. Ithaca, NY: Cornell University Press.

March, J. G., Sproull, L. S. and Tamuz, M. (1991) 'Learning From Samples of One or Fewer' Organization Science 2: 1-13.

Mayer, K. J. and Argyres, N. S. (2004) 'Learning to Contract: Evidence from the Personal Computer Industry', Organization Science 15(4): 394-410.

Mayer, K. J. and Bercovitz, J. (2008) 'The Influence of Inertia on Contract Design: Contingency Planning in Information Technology Service Contracts', Managerial \& Decision Economics 29: 149-63.

Michalski, R. S. (1994) 'Inferential Theory of Learning: Developing Foundations for Multistrategy Learning', in R. S. Michalski and G. Tecuci (eds) Machine Learning: A Multistrategy Approach, pp. 3-61. San Mateo, CA: Morgan Kaufmann.

Miller, G. A. (1956) 'The Magical Number Seven, Plus or Minus Two: Some Limits on Our Capacity for Information Processing', Psychological Review 63: 81-97.

Miner, A. S. and Mezias, S. J. (1996) 'Ugly Duckling No More: Pasts and Futures of Organizational Learning Research’, Organization Science, 7(1): 88-99. 
Oldroyd, J. B. and Gulati, R. (2010) 'A Learning Perspective on Intraorganizational Knowledge Spill-Ins', Strategic Entrepreneurship Journal 4: 356-72.

Parkhe, A. (1993) 'Strategic Alliances Structuring: A Game Theoretic and Transaction Cost Examination of Interfirm Cooperation', Academy of Management Journal 36(4): 794-829.

Prange, C. (1999) 'Organizational Learning - Desperately Seeking Theory?' in M. EasterbySmith, L. Araujo and J. Burgoyne (eds) Organizational Learning and the Learning Organization, pp. 23-44. London: Sage.

Poppo, L. and Zenger, T. (2002) 'Do Formal Contracts and Relational Governance Function as Substitutes or Complements?', Strategic Management Journal 23(8): 707-26.

Reuer, J. J. and Ariño, A. (2007) 'Strategic Alliance Contracts: Dimensions and Determinants of Contractual Complexity', Strategic Management Journal 28(3): 313-30.

Reuer, J. J., Zollo, M. and Singh, H. (2002) 'Post-Formation Dynamics in Strategic Alliances', Strategic Management Journal 23(2): 135-51.

Ricoeur, P. 1984. Time and Narrative. Chicago: University of Chicago Press.

Ring, P. S. (1997) 'Processes Facilitating Reliance on Trust in Inter-Organizational Networks', In M. Ebers (ed) The Formation of Inter-Organizational Networks, pp. 113-45. Oxford, UK: Oxford University Press.

Ring, P. S. (2002) 'The Role of Contracts in Strategic Alliances', In F. J. Contractor and P. Lorange (eds) Cooperative Strategies and Strategic Alliances, pp. 145-62. London, UK: Elsevier Science.

Ring, P. S. (2006) 'Designing Alliance Contracts: The Role of Detailed Task Descriptions', in A. Ariño and J. J. Reuer (eds) Strategic Alliances: Governance and Contracts, pp. 173-83. London, UK: Palgrave Macmillan.

Ring, P. S. and Van de Ven, A. H. (1992) 'Structuring Cooperative Relationships Between Organizations', Strategic Management Journal 13: 483-98.

Ring, P. S. and Van de Ven, A. H. (1994) 'Developmental Processes of Cooperative Interorganizational Relationships', Academy of Management Review 19(1): 90-118.

Ryall, M. D. and Sampson, R. C. (2009) 'Formal Contracts in the Presence of Relational Enforcement Mechanisms: Evidence From Technology Development Projects', Management Science 55: 906-25.

Salk, J. E. (2005) 'Often Called For But Rarely Chosen: Alliance Research that Directly Studies Process', European Management Review 2(2): 117-22.

Sampson, R. C. (2004) 'The Cost of Misaligned Governance in R\&D Alliances', Journal of Law, Economics, \& Organization 20(2): 484-526.

Sarkar, M. B., Aulakh, P. S. and Madhok, A. (2009) 'Process Capabilities and Value Generation in Alliance Portfolios', Organization Science 20(3): 583-600.

Sawyer, R. K. (1999) 'The Emergence of Creativity', Philosophical Psychology 12(4): 447-69.

Simonin, B. L. (1997) 'The Importance of Collaborative Know-How: An Empirical Test of the Learning Organization', Academy of Management Journal 40(5): 1150-74.

Suchman, M. C. (2003) 'The Contract as Social Artifact', Law \& Society Review 37(1): 91-142.

Szulanski, G., Porac, J. and Doz, Y. (2005) Strategy Process. Advances in Strategic Management, Volume 22. Oxford, UK: Elsevier.

Terlaak, A. and Gong, Y. (2008) 'Vicarious Learning and Inferential Accuracy in Adoption Processes', Academy of Management Review 33(4): 846-68. 
Tsoukas, H. (2009) 'A Dialogical Approach to the Creation of New Knowledge in Organizations', Organization Science 20(6): 941-57.

Van de Ven, A. (1992) 'Suggestions for Studying Strategy Research', Strategic Management Journal 13: 169-88.

Van der Velde, M., Jansen, P. and Anderson, N. (2004) Guide to Management Research Methods. Oxford, UK: Blackwell Publishing.

Van Maanen, J. (1979) 'The Fact of Fiction in Organizational Ethnography', Administrative Science Quarterly 24: 539-50.

Vanneste, B. S. and Puranam, P. (2010) 'Repeated Interactions and Contractual Detail: Identifying the Learning Effect', Organization Science 21: 186-201.

Vlaar, P. W. L., Klijn, E., Ariño, A. and Reuer, J. J. (2010) 'Pre-Formation Processes in Interorganizational Relations: Determinants of Search and Negotiation Efforts', In T. K. Das (ed) Researching Strategic Alliances: Emerging Perspectives. Information Age Publishing.

Vlaar, P. W. L., Van Den Bosch, F. A. J. and Volberda, H. W. (2007) 'On the Evolution of Trust, Distrust, and Formal Coordination and Control in Interorganizational Relationships: Toward an Integrative Framework', Group \& Organization Management 32: 407-31.

Weber, L. and Mayer, K. J. (2011) 'Designing Effective Contracts: Exploring the Influence of Framing and Expectations', Academy of Management Review 36.

Weber, L., Mayer, K. J. and Macher, J. T. (2011) 'An Analysis of Extendibility and Early Termination Provisions: The Importance of Framing Duration Safeguards', Academy of Management Journal 54.

Weber, L., Mayer, K. J. and Wu, R. (2009) 'The Future of Interfirm Contract Research: Opportunities Based on Prior Research and Nontraditional Tools', Advances in Strategic Management 26: 123-45.

Williamson, O. E. (1975) Markets and Hierarchies: Analysis and Antitrust Implications. New York: Free Press.

Williamson, O. E. (1985) The Economic Institutions of Capitalism: Firms, Markets, Relational Contracting. New York: Free Press.

Williamson, O. E. (1999) 'Strategy Research: Governance and Competence Perspectives', Strategic Management Journal 20: 1087-1108.

Yin, R. K. (2009) Case Study Research: Design and Methods. Newbury Park, CA: Sage.

Zajac, E. J. and Olsen, C. P. (1993) 'From Transaction Cost to Transactional Value Analysis: Implications for the Study of Interorganizational Strategies', Journal of Management Studies 31: 131-45.

Zollo, M., Reuer, J. J. and Singh, H. (2002) 'Interorganizational Routines and Performance in Strategic Alliances', Organization Science 13(6): 701-13.

Zollo, M. and Singh, H. (2004) 'Deliberate Learning in Corporate Acquisitions: Post-Acquisition Strategies and Integration Capability in US Bank Mergers', Strategic Management Journal 25(13): 1233-56.

Zollo, M. and Winter, S. G. (2002) 'Deliberate Learning and the Evolution of Dynamic Capabilities', Organization Science 13(3): 339-51. 